\title{
Phosphorus and metals immobilization by periphyton in a shallow eutrophic reservoir
}

\author{
Imobilização de fósforo e metais pelo perifíton em um reservatório eutrófico raso
}

\section{Murilo Guimarães Balle $^{1}$ (D); Carla Ferragut ${ }^{2}$ (D); Lúcia Helena Gomes Coelho ${ }^{1}$ (D);}

\author{
Tatiane Araujo de Jesus ${ }^{1 *}$
}

${ }^{1}$ Centro de Engenharia, Modelagem e Ciências Sociais Aplicadas, Universidade Federal do ABC, Av. dos Estados, 5001, Bairro Bangú, CEP 09210-580, Santo André, SP, Brasil

${ }^{2}$ Núcleo de Pesquisas em Ecologia, Instituto de Botânica de São Paulo, Secretaria do Meio Ambiente. Av. Miguel Stefano, 3687, Água Funda, CEP 04301-902, São Paulo, SP, Brasil

*e-mail: tatiane.jesus@ufabc.edu.br

Cite as: Balle, M.G. et al. Phosphorus and metals immobilization by periphyton in a shallow eutrophic reservoir. Acta Limnologica Brasiliensia, 2021, vol. 33, e11.

Abstract: Aim: This study evaluated and compared the changes in the Total Phosphorus (TP) and metals $(\mathrm{Cd}, \mathrm{Cu}, \mathrm{Ni}$ and $\mathrm{Pb})$ contents and accumulation rates in the periphyton on different substrate types (PET and glass) in wet and dry periods in a shallow eutrophic reservoir. Thus, the potential of periphyton as a green biotechnology to remediate the eutrophication and promoting metal uptake were investigated. Methods: Floating substrate carriers made of wood $(n=3)$ containing glass and PET slides were submerged close to a sewage inflow site. Substrate exposure time was about 33 days in each period. Results: Periphyton TP and metal contents $(\mathrm{Cu}, \mathrm{Ni}$ and $\mathrm{Pb})$ were influenced by seasonality and the highest contents were found in the wet period. Periphyton metal contents were significantly different between glass or PET substrates, but no differences were detected in the TP contents. Conclusions: Seasonality was a determining factor for immobilization of TP and metals in periphyton. The highest potential of TP and metals immobilization by periphyton were detected in the wet period. Our results provided insights that the periphyton can contribute to remediate eutrophication and metal removal in aquatic ecosystems.

Keywords: bioremediation; eutrophication; metals; PET reuse; tropical reservoir.

Resumo: Objetivo: Este estudo avaliou e comparou as alteraçóes nos teores e taxas de acumulação de fósforo total (PT) e metais ( $\mathrm{Cd}, \mathrm{Cu}, \mathrm{Ni}$ e $\mathrm{Pb}$ ) no perifíton em diferentes tipos de substratos (PET e vidro) nos períodos chuvoso e seco em um reservatório eutrófico raso. Assim, o potencial do perifíton como uma biotecnologia verde para remediar a eutrofizaçáo e promover a remoção de metais foi investigado. Métodos: Substratos flutuantes de madeira $(n=3)$ contendo lâminas de vidro e PET foram submersos próximos a uma entrada de esgoto. $\mathrm{O}$ tempo de exposição do substrato foi de cerca de 33 dias em cada período. Resultados: Os teores de PT e de metais ( $\mathrm{Cu}, \mathrm{Ni}$ e $\mathrm{Pb}$ ) no perifíton foram influenciados pela sazonalidade e os maiores valores foram encontrados na estaçáo chuvosa. O conteúdo de metais do perifíton foi significativamente diferente entre os substratos de vidro e PET, mas nenhuma diferença foi detectada com o conteúdo de PT. Conclusóes: A sazonalidade foi um fator determinante para a imobilizaçáo de PT e metais no perifíton. O maior potencial de imobilizaçáo de PT e metais pelo perifíton foi detectado no período chuvoso. Nossos resultados forneceram boas indicações de que o perifíton pode contribuir para remediar a eutrofização e remover metais em ecossistemas aquáticos.

Palavras-chave: biorremediação; eutrofização; reuso de PET; reservatório tropical. 


\section{Introduction}

Eutrophication is a well-known phenomenon worldwide, but still affects many aquatic ecosystems, especially in developing countries (Schindler, 2012; Jeppesen et al., 2017; Wang et al., 2018). Phosphorus $(\mathrm{P})$ is considered the main nutrient related to eutrophication and the limiting nutrient for the algal growth in most of lakes and reservoirs (Schindler et al., 2009; Schindler, 2012). Raw sewage or inadequately treated wastewater contains high P concentrations (and other pollutants) and this is an important $P$ source to aquatic ecosystems. However, in general, only the elimination of external $\mathrm{P}$ input to the ecosystem is not enough to reverse eutrophication. This is mainly because the sediment has high P stocks, which can provide $\mathrm{P}$ to the water column for a long time (Søndergaard et al., 2013, Tu et al., 2019), depending on the condition of oxygenation and $\mathrm{pH}$, for example. Considering that the internal P loading can maintain eutrophication, including restored systems, the development of efficient in situ phosphorus removal technologies can be beneficial to remediate eutrophic ecosystems.

Several in situ remediation techniques of eutrophic aquatic environments have been reported in the literature, such as: biomanipulation (e.g.: fish and macrophyte) (Zhao et al., 2012; Liu et al., 2018; Chen et al., 2020), adsorbents (e.g.: Phoslock $^{\circledR}$ and lanthanum modified bentonite application) (Yamada-Ferraz et al., 2015; van Oosterhout et al., 2020) and sediment capping (Cooke et al., 2005). However, according to these references, some disadvantages are involved in these methods, such as risks for aquatic biota and possible resuspension of $\mathrm{P}$ and metals from sediment. Bioremediation, the use of microbial organisms or processes to degrade environmental pollutants, is among the technologies most widely studied (Wu et al., 2017; Boopathy, 2000). Thereby, the use of periphyton management may be another tool for bioremediation of eutrophic shallow lakes and reservoirs, as pointed by review studies (Wu et al., 2010; 2017) and field experiments (Jöbgen et al., 2004, Morashashi et al., 2019).

Periphyton plays several roles in removing $\mathrm{P}$ from the water column, including $\mathrm{P}$ uptake and deposition, filtering particulate $\mathrm{P}$ from the water, and attenuating flow, which decreases advective transport of particulate and dissolved $\mathrm{P}$ from sediments (Dodds, 2003). Besides, periphyton has the capacity to uptake and to adsorb organic and inorganic substances (Hill, 1996). The extracellular polysaccharides matrix (EPS) excreted by bacteria and algae constitutes sorption sites for various inorganic and organic substances (Lock et al., 1984; Lu et al., 2014). In addition to immobilization of phosphorus and other nutrients, the highly diverse periphytic matrix can also immobilize metals (Vymazal, 1984; Duong et al., 2008). The relationship between metals and phosphorus concentration has been investigated on several aspects in the periphyton. Among them, the reduction of metal toxicity in the presence of high P availability (Chen, 1994). Furthermore, the metals can influence the nutrient limitation of the periphytic algae community (Paulsson et al., 2002). Based on culture experiments, Serra et al. (2010) demonstrated that $\mathrm{P}$ availability and periphyton $\mathrm{P}$ content are modulating factors of algal toxicological response to Copper $(\mathrm{Cu})$. However, the dynamic of the phosphorus and metals in the periphyton is not yet fully understood.

Numerous studies have reported that substrate type can strongly influence the development of the periphyton and, consequently, affect community responses to environmental change (e.g.: Zhang et al., 2013; Trbojević et al., 2018, Morashashi et al., 2019, Cao et al., 2019). Glass slides are the most used artificial substrate in ecological studies (Trbojević et al., 2018) since it is inert and has a regular surface. Comparing different substrate types, Cao et al. (2019) observed lower pigments concentration and algal richness and diversity in the periphyton on plastic, which had a smooth surface and an unfavorable position. However, in a bioremediation perspective, plastic has some advantages, since it is more resistant, lighter, and cheaper than glass, and more portable than sand or stones. Plastic substrates were successfully utilized to periphyton growth previously (Milstein, Peretz and Harpaz, 2009; Cao et al., 2019; Morashashi et al., 2019). Though, the relationship between substrate type and efficiency of periphyton in immobilizing phosphorus and metals needs to be further investigated.

In the present study, we evaluated and compared the differences in the periphyton TP and metals $(\mathrm{Cd}, \mathrm{Cu}, \mathrm{Ni}$ and $\mathrm{Pb})$ content and accumulation rates using different substrates (PET and glass slides) in the wet and dry periods in a shallow eutrophic reservoir. We hypothesized that periphyton on PET and glass slides can be used to remove TP and metals from eutrophic water and it can be used as a bioremediation strategy in a shallow reservoir. 


\section{Material and Methods}

\subsection{Study area, experimental design, and sampling}

The present study was conducted in Garças Reservoir (2338'40.6” S, 46³7'28.0” W). This reservoir is located at the Parque Estadual das Fontes do Ipiranga Biological Reserve (PEFI), situated in the Municipality of São Paulo, southeastern Brazil (Figure 1). The reservoir presents $88.156 \mathrm{~m}^{2}$ of surface area, with average and maximum depth of $2.1 \mathrm{~m}$ and $4.7 \mathrm{~m}$, respectively. The mean residence time is 71 days, and the mean volume is $188.785 \mathrm{~m}^{3}$ (Bicudo et al., 2002). Bicudo et al. (2007) documented a pronounced proliferation of water hyacinths (Eichhornia crassipes (Mart.) Solms) from 1998-1999, occupying 40-70\% of the reservoir surface area. Since the end of 1999, and triggered by the mechanical removal of plants, the reservoir abruptly shifted to a stable degraded state with permanent cyanobacterial blooms. According to a recent study, cyanobacterial dominance ceased, and the invasive species, Ceratium furcoides (Levander) Langhans, apparently is the dominant species (Crossetti et al., 2019). The studied area is characterized by two climatic periods along the year: wet period with high temperature (mean $=21.4^{\circ} \mathrm{C} \pm 2.7$; September-February) and dry period with low air temperature $\left(\right.$ mean $=18.4^{\circ} \mathrm{C}$ \pm 2.3 ; March-August) (http://www.estacao.iag.usp. br/boletim.php).
Three floating substrate carriers were submerged close to a sewage inflow site. The experimental apparatus was installed $30 \mathrm{~cm}$ bellow water surface at sites with $2.5 \mathrm{~m}$ depth. Each substrate carrier held 50 glass slides $\left(38.24 \pm 0.02 \mathrm{~cm}^{2}\right)$ and 50 PET slides $\left(40.80 \pm 1.33 \mathrm{~cm}^{2}\right)$. PET slides were chosen because they are low cost and easy to handle. Glass slides were used as a reference substrate to comparison, since is the most used in ecological studies (Trbojević et al., 2018).

Sampling was performed in wet and dry periods, based on the seasonal variation of periphyton biomass (Borduqui \& Ferragut, 2012). Periphyton colonization time was 37 days in the wet period $(12 / 17 / 2013$ to $01 / 23 / 2014)$ and 28 days in the dry period (04/29/2014 to $05 / 27 / 2014)$. The differences in colonization periods were due to storms in the wet period and logistic issues. However, the accumulation rate was normalized to enable data comparison. Thus, ten slides of each type of substrate colonized by periphyton were removed randomly from each carrier, totalizing 30 glass and 30 PET slides in each period (wet and dry).

The periphyton was removed from the substrate by scraping and washing with ultrapure water for determination of biomass, TP, and metals' contents. Water samples from $30 \mathrm{~cm}$ depth and surface sediment samples were collected in wet and dry periods, in triplicate. Water samples were collected using a van Dorn horizontal sampler (5 L) and
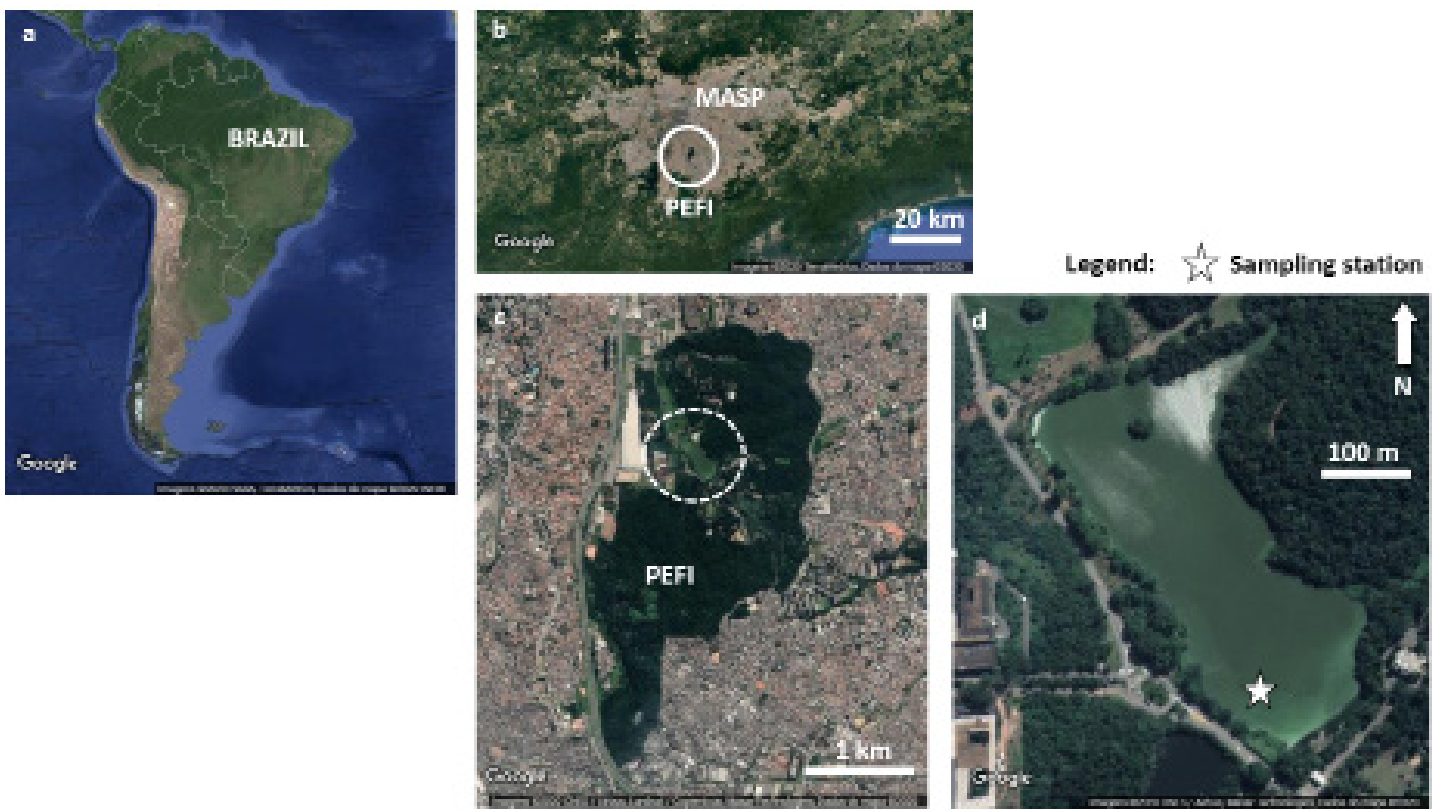

Figure 1. (a) Brazil; (b) Location of Metropolitan Area of São Paulo (MASP) with PEFI area circled; (c) Location of Garças Reservoir in PEFI. (d) Sampling station in Garças Reservoir. Source: Google, NASA, TerraMetrics, INEGI, CNES/ Airbus, Landsat/ Copernicus, Maxar Technologies. 
a Kajak collector was used to sample the recent sediment from the top.

\subsection{Analyzed variables}

On the sampling day, temperature, electrical conductivity, turbidity, and total dissolved solids in the water column were measured using a multiparameter probe (Model Hi 9829 from Hanna $\left.{ }^{\circledR}\right)$. TP concentrations were determined in the water, sediment and periphyton samples. Water TP analyzes were performed on unfiltered water samples by persulphate oxidation method (Valderrama, 1981). Sediment and periphyton TP contents were determined by combusting samples at $550{ }^{\circ} \mathrm{C}$ for $1 \mathrm{~h}$ and then digested in $\mathrm{HCl} 1 \mathrm{~N}$ at $80^{\circ} \mathrm{C}$ for 30 min (Andersen, 1976). Then, TP concentration $\left(\mu \mathrm{g} \mathrm{L}^{-1}\right)$ was determined by the ascorbic acid method (Method 4500-P E) according to APHA (2012). We determined the periphyton dry mass (DM) and ash free dry mass (AFDM) by difference of mass after drying in an oven at $100^{\circ} \mathrm{C}$ until constant mass and after calcination at $550^{\circ} \mathrm{C}$. Since was not possible to standardize the colonization time due to the climate and logistics (37 days in wet period and 28 days in dry period), we have normalized data by days of colonization to enable its comparison, originating TP Accumulation Rate, TP-AR (mg TP $\left.\mathrm{m}^{-2} \mathrm{~d}^{-1}\right)$, according to Equation 1.

$T P A R=\frac{T P}{\text { area } \times \text { time }}$

Where: TP mass in the periphyton (mg); area is the surface area of the substrate slide used in TP analyze $\left(\mathrm{m}^{2}\right)$; and time is the exposure time of the substrate slide in the environment (days).

Metal $(\mathrm{Cd}, \mathrm{Cu}, \mathrm{Pb}$ and $\mathrm{Ni})$ concentrations were determined by Flame Atomic Absorption Spectrometry (FAAS) (APHA, 2012). Periphyton and sediment samples were digested by the addition of ultrapure water and concentrated nitric acid. The limit of detection (LD) and limit of quantification (LQ) to metals were $(\mathrm{n}=10, \mathrm{LD} / \mathrm{LQ}): \mathrm{Cd}\left(0.03 / 0.1 \mathrm{mg} \mathrm{L}^{-1}\right)$; $\mathrm{Cu}\left(0.08 / 0.26 \mathrm{mg} \mathrm{L}^{-1}\right) ; \mathrm{Pb}\left(0.3 / 1.0 \mathrm{mg} \mathrm{L}^{-1}\right)$; $\mathrm{Ni}\left(0.1 / 0.33 \mathrm{mg} \mathrm{L}^{-1}\right)$. The metal accumulation rate on periphyton was calculated according to Equation 1, changing TP concentration by metal concentration. This equation was used to normalize the dry mass accumulation as well.

\section{Statistical analysis}

The significant differences in periphyton TP and metal contents among substrate types (PET and glass slides) and climatic periods were examined using two-way Analysis of Variance (ANOVA). ANOVA assumptions were previously tested, and log data transformed when necessary. Descriptive and exploratory univariate analyzes were performed using statistical software SigmaPlot 12.0 (Systat Software Inc). Microsoft Excel and Origin ${ }^{\circledR}$ were also used to graphical constructions.

\section{Results}

\subsection{Climate variables}

During the wet period, the average air temperature was $23.5 \pm 1.9^{\circ} \mathrm{C}$. In the dry period the average temperature was $18.0 \pm 1.8^{\circ} \mathrm{C}$ (Figure 2a). Regarding to the rainfall, in the wet period, the average daily rainfall was $5.1 \mathrm{~mm}$ and the accumulated rainfall for the days of the experiment was $193.6 \mathrm{~mm}$. In the dry period, the average daily rainfall was $2.1 \mathrm{~mm}$ and the accumulated rainfall in the period was $61.3 \mathrm{~mm}$ (Figure 2b).

\subsection{Water}

The results of the physical and chemical variables of the $30 \mathrm{~cm}$ depth water are summarized in the Table 1 . The wet period was characterized by the highest values of water temperature, turbidity, $\mathrm{pH}$, electrical conductivity, and TP concentrations. Water TP concentrations were significantly different between wet and dry periods (one-way ANOVA: $\mathrm{F}=31.93 ; p=0.0002$ ).

\subsection{Sediment}

Table 2 summarizes TP and metal concentrations in the sediment samples. No significant difference
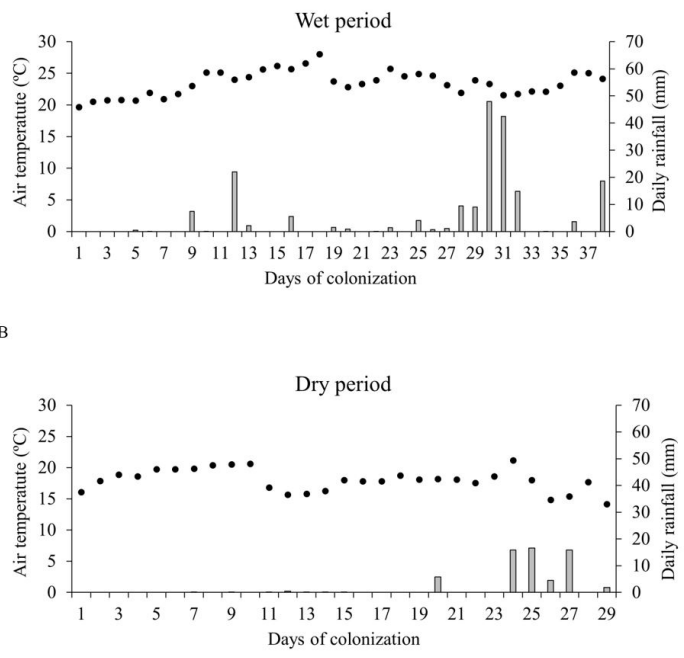

Figure 2. Air temperature $\left({ }^{\circ} \mathrm{C}\right)$ and daily rainfall $(\mathrm{mm})$ during the (A) wet and (B) dry periods. 
was found in the sediment TP contents between climatic periods. However, $\mathrm{Cu}, \mathrm{Ni}$ and $\mathrm{Pb}$ contents in the sediment were significantly different between climatic periods. Cd was below LD of the method $\left(0.03 \mathrm{mg} \mathrm{L}^{-1}\right)$ in both periods.

\subsection{Periphyton}

The highest dry mass (DM) of the periphyton were found in the wet period in both types of substrates (Table 3). Significant difference in periphyton DM was found between climatic periods (two-way ANOVA: $\mathrm{F}=58.88 ; p<0.001$ ). Again, the higher DM accumulation rate in the periphyton was found in the wet period (two-way ANOVA: $\mathrm{F}=30.35 ; p<0.001$ ). Total phosphorus concentrations varied from 390.94 to $495.57 \mathrm{mg} \mathrm{kg}^{-1}$. Cd was below of the detection

Table 1. Results of abiotic variables in the water $(30 \mathrm{~cm}$ depth) at Garças Reservoir during wet and dry periods.

\begin{tabular}{|c|c|c|}
\hline \multirow{2}{*}{ Variables } & \multicolumn{2}{|c|}{ Periods } \\
\hline & Wet & Dry \\
\hline Water temperature $\left({ }^{\circ} \mathrm{C}\right)$ & 27.4 & 21.3 \\
\hline $\mathrm{pH}$ & 9.83 & 7.61 \\
\hline Electrical conductivity $\left(\mu \mathrm{S} \mathrm{cm} \mathrm{cm}^{-1}\right)$ & 268 & 289 \\
\hline Turbity (NTU) & 121 & 100 \\
\hline Total dissolved solids $\left(\mathrm{mg} \mathrm{L}^{-1}\right)$ & 174 & 150 \\
\hline Water total phosphorus $\left(\mu \mathrm{g} \mathrm{L}^{-1}\right)$ & 116.2 & 60.8 \\
\hline
\end{tabular}

limit in both periods. $\mathrm{Cu}$ and $\mathrm{Ni}$ showed the highest concentrations in the wet period, reaching $37.22 \mathrm{mg} \mathrm{kg}^{-1}$ (Table 3).

The highest periphyton TP-AR were found in the wet period in both substrate types (Figure 3a and Table 4). TP content in the periphyton was significantly different between periods (two-way ANOVA: $\mathrm{F}=209.22 ; p<0.001)$, but there was no statistical difference among substrates, as well the interaction among factors. Regarding the metal accumulation rates, the cadmium content in the periphyton on the PET and glass substrates was below the $\mathrm{LD}$, while $\mathrm{Cu}, \mathrm{Ni}$ and $\mathrm{Pb}$ on both substrates were higher in the wet period (Figures $3 \mathrm{~b}-\mathrm{d}$ ). Differences among $\mathrm{Cu}, \mathrm{Ni}$ and $\mathrm{Pb}$ accumulation rates were found between climatic periods (two-way ANOVA: $p<0.001$ ); and substrate types only for $\mathrm{Cu}$ and $\mathrm{Ni}$ (two-way ANOVA: $p<0.003$ ) (Figures 3 b,c). However, the interaction between the factors was significant for $\mathrm{Cu}$ and $\mathrm{Ni}$ (two-way ANOVA: $p<0.049$ ). Cu-AR was significantly higher in periphyton on PET substrate in the wet period.

\section{Discussion}

We found that TP and metal accumulation rates $(\mathrm{Cu}, \mathrm{Ni}$ and $\mathrm{Pb})$ in the periphyton were influenced by seasonality and the highest levels

Table 2. Mean values and standard deviation $(n=6)$ of total phosphorus and metal concentrations in the sediment samples of Garças Reservoir during the wet and dry periods. Results are expressed in dry mass (DM). Limit of detection (LD) to Cd was $0.03 \mathrm{mg} \mathrm{L}^{-1}$. ns = no significant difference.

\begin{tabular}{|c|c|c|c|c|}
\hline \multirow{2}{*}{ Variables } & \multicolumn{2}{|c|}{ Periods } & \multicolumn{2}{|c|}{ one-way ANOVA } \\
\hline & Wet & Dry & $\mathbf{F}$ & $p$ \\
\hline TP (mg kg-1 DM) & $469.14( \pm 48.75)$ & $421.24( \pm 82.46)$ & $n s$ & $n s$ \\
\hline $\mathrm{Cd}\left(\mathrm{mg} \mathrm{kg}{ }^{-1} \mathrm{DM}\right)$ & $<$ LD & $<$ LD & - & - \\
\hline $\mathrm{Cu}$ (mg kg-1 DM) & $61.97( \pm 32.88)$ & $1.22( \pm 0.64)$ & 9,763 & $<0.0001$ \\
\hline $\mathrm{Ni}\left(\mathrm{mg} \mathrm{kg} \mathbf{~}^{-1} \mathrm{DM}\right)$ & $8.38( \pm 4.67)$ & $0.91( \pm 0.50)$ & 4.6 & $<0.0001$ \\
\hline $\mathrm{Pb}$ (mg kg-1 DM) & $2.83( \pm 1.55)$ & $0.19( \pm 0.10)$ & 4,883 & 0.0002 \\
\hline
\end{tabular}

Table 3. Average and standard deviation $(n=3)$ of dry mass (DM), ash free dry mass (AFDM), dry mass accumulation rate (DM-AR), total phosphorus and metal concentrations in the periphyton on glass and PET slides in wet and dry periods in a eutrophic reservoir. Limit of detection (LD) to Cd was $0.03 \mathrm{mg} \mathrm{L}^{-1}$.

\begin{tabular}{|c|c|c|c|c|}
\hline \multirow{2}{*}{ Variables } & \multicolumn{2}{|c|}{ Wet period } & \multicolumn{2}{|c|}{ Dry period } \\
\hline & Glass & PET & Glass & PET \\
\hline $\mathrm{DM}$ (mg) & $407.67( \pm 92.59)$ & $453.00( \pm 34.77)$ & $215.79( \pm 17.31)$ & $194.69( \pm 16.41)$ \\
\hline AFDM (mg) & $128.00( \pm 42.58)$ & $166.67( \pm 28.88)$ & $95.58( \pm 2.70)$ & $85.61( \pm 3.16)$ \\
\hline DM-AR $\left(\mathrm{mg} \mathrm{m}^{-2} \mathrm{~d}^{-1}\right)$ & $5.76( \pm 1.32)$ & $6.00( \pm 0.46)$ & $4.03( \pm 0.32)$ & $3.47( \pm 0.29)$ \\
\hline TP (mg kg-1 DM) & $390.94( \pm 101.77)$ & $415.71( \pm 55.32)$ & $450.53( \pm 53.39)$ & $495.57( \pm 57.49)$ \\
\hline $\mathrm{Cd}\left(\mathrm{mg} \mathrm{kg}^{-1} \mathrm{DM}\right)$ & $<\mathrm{LD}$ & $<L D$ & $<$ LD & $<L D$ \\
\hline $\mathrm{Cu}\left(\mathrm{mg} \mathrm{kg}^{-1} \mathrm{DM}\right)$ & $14.00( \pm 5.66)$ & $37.22( \pm 1.43)$ & $1.67( \pm 0.14)$ & $1.69( \pm 0.13)$ \\
\hline $\mathrm{Ni}\left(\mathrm{mg} \mathrm{kg}^{-1} \mathrm{DM}\right)$ & $37.22( \pm 1.43)$ & $21.19( \pm 0.04)$ & $1.13( \pm 0.01)$ & $1.12( \pm 0.01)$ \\
\hline $\mathrm{Pb}\left(\mathrm{mg} \mathrm{kg}^{-1} \mathrm{DM}\right)$ & $10.66( \pm 2.44)$ & $7.28( \pm 0.19)$ & $0.26( \pm 0.03)$ & $0.26( \pm 0.01)$ \\
\hline
\end{tabular}



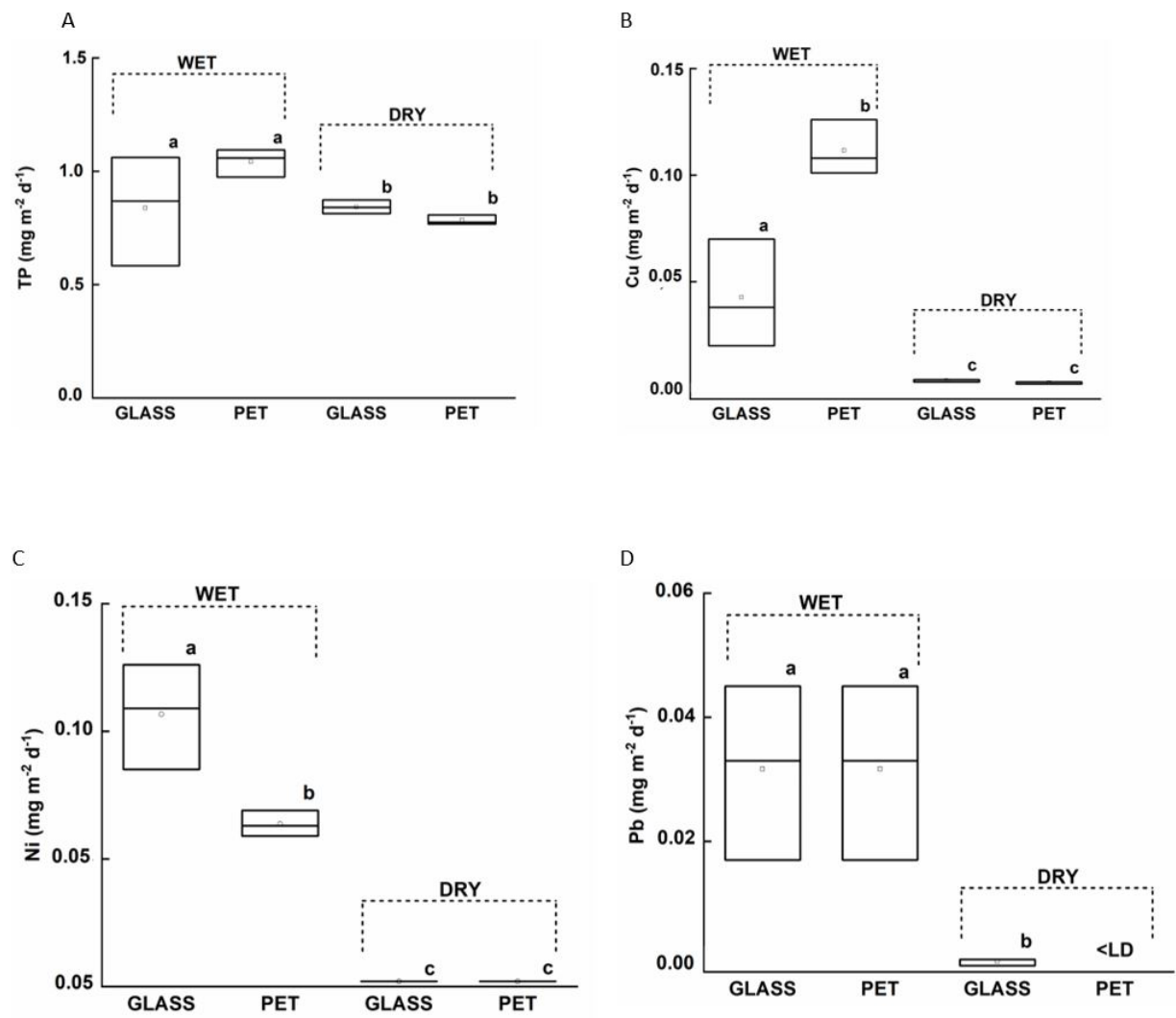

Figure 3. (A) Total phosphorus, TP; (B) Copper, Cu; (C) Nickel, Ni; and (D) Lead, Pb accumulation rates $\left(\mathrm{mg} \mathrm{m}^{-2} \mathrm{~d}^{-1}\right)$ on periphyton dry mass over glass and PET substrates in the wet and dry periods. Cd was bellow detection limit $\left(0.003 \mathrm{mg} \mathrm{L}^{-1}\right)$. Different letters indicate significant difference in ANOVA two-way followed by Tukey test $(\mathrm{p}<0.05)$.

Table 4. Mean and standard deviation $(\mathrm{n}=3$; $\mathrm{SD})$ of the accumulation rates $\left(\mathrm{AR}, \mathrm{mg} \mathrm{m}^{-2} \mathrm{~d}^{-1}\right)$ of total phosphorus and metals on glass and PET substrates during the wet and dry periods in a eutrophic shallow lake. Limit of detection (LD) to Cd was $0.03 \mathrm{mg} \mathrm{L}^{-1}$; ns = no significant difference. Statistical significance $=0.05$.

\begin{tabular}{|c|c|c|c|c|c|c|c|}
\hline \multirow{3}{*}{ Variables } & \multirow{2}{*}{\multicolumn{2}{|c|}{ Wet period }} & \multirow{2}{*}{\multicolumn{2}{|c|}{ Dry period }} & \multirow{2}{*}{\multicolumn{3}{|c|}{$\begin{array}{c}\text { two-way ANOVA } \\
p \text { and } F \text { values }\end{array}$}} \\
\hline & & & & & & & \\
\hline & Glass & PET & Glass & PET & Period & Substrate & Interaction \\
\hline TP-AR $\left(\mathrm{mg} \mathrm{m}^{-2} \mathrm{~d}^{-1}\right)$ & $1.00 \pm 0.23$ & $1.24 \pm 0.06$ & $0.90 \pm 0.03$ & $0.84 \pm 0.02$ & $\begin{array}{l}p<0.001 \\
(209.22)\end{array}$ & $n s$ & ns \\
\hline Cd-AR $\left(\mathrm{mg} \mathrm{m}^{-2} \mathrm{~d}^{-1}\right)$ & $<L D$ & $<L D$ & $<L D$ & $<L D$ & - & - & - \\
\hline Cu-AR (mg m-2 $\left.\mathrm{d}^{-1}\right)$ & $0.043 \pm 0.025$ & $0.112 \pm 0.013$ & $0.003 \pm 0.001$ & $2.9 E^{-3} \pm 0.5 E^{-3}$ & $<0.001(81.15)$ & $0.003(17,468)$ & $0.003(17,952)$ \\
\hline $\operatorname{Ni}-A R\left(\mathrm{mg} \mathrm{m}^{-2} \mathrm{~d}^{-1}\right)$ & $0.107 \pm 0.021$ & $0.064 \pm 0.005$ & $2.3 \mathrm{E}^{-3} \pm 0.2 \mathrm{E}^{-3}$ & $1.9 E^{-3} \pm 0.2 E^{-3}$ & $<0.001(2,636)$ & $0.001(22,646)$ & $0.049(5,385)$ \\
\hline $\operatorname{Pb}-A R\left(\mathrm{mg} \mathrm{m}^{-2} \mathrm{~d}^{-1}\right)$ & $0.032 \pm 0.013$ & $0.022 \pm 0.002$ & $5.3 E^{-4} \pm 1.0 E^{-4}$ & $4.4 E^{-4} \pm 0.6 E^{-4}$ & $<0.001(645)$ & ns & ns \\
\hline
\end{tabular}

were found in the wet period. In this period, limnological conditions were characterized by higher temperature, $\mathrm{pH}$, and $\mathrm{TP}$ concentration. The temperature is one of the main factors that act on the phase of algae uptake that is dependent on metabolism, which is the longest phase of the process (Genter, 1996). Several studies have reported the positive effect of temperature on algal uptake (e.g.: Zeng \& Wang, 2011), as well as the association of periphyton TP content with P availability in the water (Gaiser et al., 2004). As reported in other studies, seasonality may influence the immobilization of metals and TP in the periphyton biomass (Duong et al., 2008; Ferragut et al., 2010). Therefore, the seasonality was a determining factor for the immobilization of $\mathrm{TP}$ and metals in the periphyton in the eutrophic reservoir studied. Therefore, our findings suggest that wet period with high water temperature may support the application of remediation techniques using periphyton.

In addition to the higher accumulation rates of TP and metals, the highest periphyton DM and DM-AR increment on the glass and PET 
substrates were found in the wet period. Similarly, previous studies reported the highest DM increment during the wet period, when the community has low algal biomass (Oliveira et al., 2010; Borduqui \& Ferragut, 2012; C. F. unpublished data). The low algal biomass in the periphyton is commonly associated with the strong shading caused by phytoplankton bloom in eutrophic reservoirs (Borduqui and Ferragut, 2012; Trbojević et al., 2017). Light can increase accumulative effects of metals in the periphyton due to the relationship between metal absorption and photosynthesis, which may be a result of active absorption, cation exchange adsorption or precipitation (Gray \& Hill, 1995; Bere et al., 2012). In the present study, the periphyton TP and metal contents increase may occur even in low light availability due to the intense phytoplankton bloom, which always occurs in the wet period (Crossetti et al., 2019). Other factors act on the $\mathrm{P}$ and metal assimilation and adsorption, as temperature and $\mathrm{pH}$, both were higher in the wet than in the dry period. While the temperature can modulate the metal bioaccumulation in periphyton (Lambert et al., 2016), the high pH (> 8.0) does not seem to stimulate both P (Zhou et al., 2005) and metals (Lin et al., 2020). Although the external condition does not seem to stimulate bioaccumulation, micro-environmental conditions can be self-induced by periphyton metabolism and growth. Increasing the thickness of the periphytic matrix can reduce the external dependence of the community (Roeselers et al., 2008). Considering that the algae act significantly in the immobilization of TP and metals in the periphyton (Lin et al., 2020), the immobilization potential of the community could be impaired. Although low algal biomass in the periphyton can occur in low light availability, mixotrophic algae and luxury $\mathrm{P}$ consumption can contribute to the storage of $\mathrm{P}$ in the community (Stevenson \& Stoermer, 1982; Granéli et al., 1999). The ingestion of bacteria and particulate material by mixotrophic species may be a source of phosphorus (Jones, 2000). Numerous species of algae can store phosphorus in polyphosphate bodies (Guzzon et al., 2008), in this case, species with low light requirements. Thus, algae present adaptive strategies for efficient TP assimilation, and probably metals, in low light availability. Possibly, algae with luxury $\mathrm{P}$ consumption and mixotrophic can make periphyton more efficient in bioremediation. The immobilization potential of TP and metals by the components of the periphyton needs to be further investigated in tropical lakes and reservoirs, especially in eutrophic conditions.
Considering the substrate type, we found that only the periphyton metal accumulation rates were significantly different between glass or PET substrates, but no influence was detected on the TP-AR. Although some studies have shown little or no influence of substrate type on the periphyton structure and functioning, the influence of substrate type on the community should not be ignored (Vadeboncoeur et al., 2006; Hao et al., 2017). The use of PET as an artificial substrate can be a part of an environmental-friendly technology, since PET bottles are abundant, and the material could be repurposed. In addition, PET is malleable and, according to Pereira et al. (2002), has a lower specific mass (PET: $-1.41 \mathrm{~g} \mathrm{~mL}^{-1}$; glass: $2.5 \mathrm{~g} \mathrm{~mL}^{-1}$ ), what makes the system easier to carry and be more floatable. However, due to the problem of microplastics in aquatic ecosystems (Wagner et al., 2014), the need to develop fully environmentalfriendly substrates for the use of periphyton as a bioremediator in aquatic ecosystems is emphasized. Our results showed that $\mathrm{Cu}$ was more immobilized on periphyton on PET substrate, while $\mathrm{Ni}$ and $\mathrm{Pb}$ were more immobilized on periphyton on glass substrate. Therefore, in addition to seasonality, metal immobilization in the periphyton was associated with substrate type.

According Holding et al. (2003), periphyton may be useful as biomonitor when determining the potential mobility and toxicity of the metals $\mathrm{Cu}, \mathrm{Cd}$ and $\mathrm{Zn}$ in aquatic ecosystems, particularly when used in conjunction with sediment data. In the wet period, our findings showed that $\mathrm{Cu}$ contents were higher in the sediment than in the periphyton in both substrate types, but $\mathrm{Ni}$ and $\mathrm{Pb}$ contents were higher in the periphyton. In contrast, the $\mathrm{Cu}, \mathrm{Ni}$ and $\mathrm{Pb}$ contents in the periphyton and in the sediment were similar in the dry period (Tables 2 and 3). Moreover, $\mathrm{Cu}, \mathrm{Pb}$ and Ni contents in the sediment were lower than the threshold level proposed by Wisconsin Department of Natural Resources (WDNR, 2003), which indicates the minimum level of contamination by the studied metals.

In general, metal sediment is more used in environmental monitoring (CETESB, 2020) than biofilm. However, our results suggest that periphyton metals can contribute with significant environmental information. Thus, as reported by Holding et al. (2003), periphyton and surface sediment data may be complementary in the studied reservoir. For example, Rooney et al. (2020) showed that periphyton is a sensitive method to 
detect the presence of pesticides in wetlands, since its concentrations in periphytic biomass were significantly higher than in water and sediment samples. However, attention should be paid since environmental stressors may negatively affect some components of the biofilm (e.g.: decreased bacteria and algae diversity) and positively to others (e.g.: increased fungi diversity) (Calapez et al., 2020).

In conclusion, we found that seasonality was a determining factor for the immobilization of TP and metals in the periphyton of the eutrophic reservoir studied. Our findings suggest that the greatest potential for TP and metals immobilization by periphyton occurs in the wet period. We speculate that algae with luxury $\mathrm{P}$ consumption and mixotrophic contributed to the storage of $\mathrm{P}$ and metals in periphyton in low light (intense phytoplankton bloom). Differences in $\mathrm{Ni}$ and $\mathrm{Pb}$ contents on PET and glass suggest that substrate type should be considered in the evaluation of periphyton as bioremediator. Comparing periphyton $\mathrm{TP}, \mathrm{Cu}, \mathrm{Ni}$ and $\mathrm{Pb}$ contents on glass and PET substrates with sediment surface, we found that they can be complementary data for environmental assessment and diagnosis. In addition, the metals concentrations were lower than that reported in most used agricultural phosphate fertilizers in Brazil (Camargo et al., 2000; Freitas et al., 2009), indicating that the generated biomass can be used in agricultural fertilizers. Another possible uses of periphyton biomass are biodiesel production (Kligerman \& Bouwer, 2015) and fish food (Siqueira \& Rodrigues, 2009). Finally, we found good indications that the periphyton can contribute to remediate eutrophication in aquatic ecosystems. We emphasize that further studies on the potential of periphyton in bioremediation of tropical eutrophic lakes and reservoirs are needed, especially on the role of algae in metal immobilization in the biofilm.

\section{Acknowledgements}

The authors thank to PIBIC - Conselho Nacional de Desenvolvimento Científico e Tecnológico (CNPq) for Scientific Initiation Scholarship to MGB. The authors also would like to thank the Weather Station of the Institute of Astronomy, Geophysics and Atmospheric Science of the University of São Paulo for making available the meteorological observations. Finally, we also thank UFABC Multi-User Experimental Center (CEM UFABC) by analytical facilities.

\section{References}

ANDERSEN, J.M. An ignition method for determination of total phosphorus in lake sediments. Water Resources, 1976, 10, 329-331.

AMERICAN PUBLIC HEALTH ASSOCIATION APHA. Standard methods for the examination of water and wastewater. Washington DC: APHA, 2012.

BERE, T., CHIA, M.A. and TUNDISI, J.G. Effects of $\mathrm{Cr}$ III and $\mathrm{Pb}$ on the bioaccumulation and toxicity of $\mathrm{Cd}$ in tropical periphyton communities: Implications of pulsed metal exposures. Environmental Pollution, 2012, 163, 184-191. http://dx.doi.org/10.1016/j. envpol.2011.12.028. PMid:22249022.

BICUDO, C.E.M., CARMO, C.F., BICUDO, D.C., HENRY, R., PIÁO, A.C.S., SANTOS, C.M. and LOPES, M.R.M. Morfologia e morfometria de três reservatórios do PEFI. In: D.C. BICUDO, M.C. FORTI and C.E.M. BICUDO eds. Parque Estadual das Fontes do Ipiranga: Unidade de Conservação ameaçada pela urbanização de São Paulo. São Paulo: Secretaria do Meio Ambiente do Estado de São Paulo, 2002, pp. 141-158.

BICUDO, D.C., FONSECA, B.M., BINI, L.M., CROSSETTI, L.O., BICUDO, C.E.M. and JESUS, T.A. Undesirable side-effects of water hyacinth control in a shallow tropical reservoir. Freshwater Biology, 2007, 52(6), 1120-1133. http://dx.doi. org/10.1111/j.1365-2427.2007.01738.x.

BOOPATHY, R. Factors limiting bioremediation technologies. Bioresource Technology, 2000, 74(1), 63-67. http://dx.doi.org/10.1016/S09608524(99)00144-3.

BORDUQUI, M. and FERRAGUT, C. Factors determining periphytic algae succession in a tropical hypereutrophic reservoir. Hydrobiologia, 2012, 683(1), 109-122. http://dx.doi.org/10.1007/s10750011-0943-6.

CALAPEZ, A.R., ELIAS, C.L., ALVES, A., ALMEIDA, S.F.P., BRITO, A.G. and FEIO, M.J. Shifts in biofilms' composition induced by flow stagnation, sewage contamination and grazing. Ecological Indicators, 2020, 111, 106006. http://dx.doi. org/10.1016/j.ecolind.2019.106006.

CAMARGO, M.S.D., ANJOS, A.R.M.D., ROSSI, C. and MALAVOLTA, E. Phosphate fertilizers and heavy metals in an Oxisol cultivated with rice. Scientia Agricola, 2000, 57(3), 513-518. http:// dx.doi.org/10.1590/S0103-90162000000300022.

CAO, Y., ZHANG, N., SUN, J. and LI, W. Responses of periphyton on non-plant substrates to different macrophytes under various nitrogen concentrations: A mesocosm study. Aquatic Botany, 2019, 154, 53-59. http://dx.doi.org/10.1016/j.aquabot.2019.01.003.

COMPANHIA AMBIENTAL DO ESTADO DE SÃO PAULO - CETESB. Programa de Monitoramento [online]. São Paulo: CETESB, 2020 [viewed 14 Jan. 
2020]. Available from: https://cetesb.sp.gov.br/aguasinteriores/programa-de-monitoramento/

CHEN, C.Y. Theoretical evaluation of the inhibitory effects of mercury on algal growth at various orthophosphate levels. Water Research, 1994, 28(4), 931-937. http://dx.doi.org/10.1016/00431354(94)90101-5.

CHEN, Z., ZHAO, D., LI, M., TU, W., LUO, X., and LIU, X. A field study on the effects of combined biomanipulation on the water quality of a eutrophic lake. Environmental Pollution, 2020, 265(A), 115091. https://doi.org/10.1016/j.envpol.2020.115091.

WDNR. WISCONSIN DEPARTMENT OF NATURAL RESOURCES. Consensus-Based Sediment Quality Guidelines. Recommendations for Use \& Application. Wisconsin: Department of Natural Resources, 2003. 40 p. [viewed 14 Jan. 2020]. Available from: https://www.itrcweb.org/contsedsbioavailability/References/cbsqg_interim_final.pdf

COOKE, G.D., WELCH, E.B., PETERSON, S. and NICHOLS, S.A. Restoration and management of lakes and reservoirs. Boca Raton: CRC press, 2005, 616 p.

CROSSETTI, L.O., BICUDO, D.C., BINI, L.M., DALA-CORTE, R.B., FERRAGUT, C. and BICUDO, C.E.M. Phytoplankton species interactions and invasion by Ceratium furcoides are influenced by extreme drought and water-hyacinth removal in a shallow tropical reservoir. Hydrobiologia, 2019, 831(1), 71-85. http://dx.doi.org/10.1007/ s10750-018-3607-y.

DODDS, W.K. The role periphyton in phosphorus retention in shallow freshwater aquatic systems. Journal of Phycology, 2003, 39(5), 840-849. http:// dx.doi.org/10.1046/j.1529-8817.2003.02081.x.

DUONG, T.T., MORIN, S., HERLORY, O., FEURTET-MAZEL, A., COSTE, M. and BOUDOU, A. Seasonal effects of cadmium accumulation in periphytic diatom communities of freshwater biofilms. Aquatic Toxicology (Amsterdam, Netherlands), 2008, 90(1), 19-28. http://dx.doi.org/10.1016/j.aquatox.2008.07.012. PMid:18801587.

FERRAGUT, C., RODELLO, A.F. and BICUDO, C.E.M. Seasonal variability of periphyton nutrient status and biomass on artificial and natural substrates in a tropical mesotrophic reservoir. Acta Limnologica Brasiliensia, 2010, 22(4), 397-409. http://dx.doi. org/10.4322/actalb.2011.005.

FREITAS, E.V.S., NASCIMENTO, C.W.A., GOULART, D.F. and SILVA, J.P.S. Disponibilidade de cádmio e chumbo para milho em solo adubado com fertilizantes fosfatados. Revista Brasileira de Ciência do Solo, 2009, 33(6), 1899-1907. http:// dx.doi.org/10.1590/S0100-06832009000600039.

GAISER, E.E., SCINTO, L.J., RICHARDS, J.H., JAYACHANDRAN, K., CHILDERS, D.L.,
TREXLER, J.C. and JONES, R.D. Phosphorus in periphyton mats provides the best metric for detecting low-level $\mathrm{P}$ enrichment in an oligotrophic wetland. Water Research, 2004, 38(3), 507-516. http://dx.doi.org/10.1016/j.watres.2003.10.020. PMid:14723918.

GENTER, R.B. Ecotoxicology of inorganic chemical stress to algae. In: R. JAN STEVENSON, M.L. BOTHWELL and R.L. LOWE. Algal Ecology. Academic Press, 1996. http://dx.doi.org/10.1016/ B978-012668450-6/50043-6.

GRANÉLI, E., CARLSSON, P. and LEGRAND, C. The role of $\mathrm{C}, \mathrm{N}$ and $\mathrm{P}$ in dissolved and particulate organic matter as a nutrient source for phytoplankton growth, including toxic species. Aquatic Ecology, 1999, 33(1), 17-27. http://dx.doi. org/10.1023/A:1009925515059.

GRAY, B.R. and HILL, W.R. Nickel sorption by periphyton exposed to different light intensities. Journal of the North American Benthological Society, 1995, 14(2), 299-305. http://dx.doi. org/10.2307/1467781.

GUZZON, A., BOHN, A., DIOCIAIUTI, M. and ALBERTANO, P. Cultured phototrophic biofilms for phosphorus removal in wastewater treatment. Water Research, 2008, 42(16), 4357-4367. http://dx.doi.org/10.1016/j.watres.2008.07.029. PMid:18774156.

HAO, B., WU, H., CAO, Y., XING, W., JEPPESEN, E. and LI, W. Comparison of periphyton communities on natural and artificial macrophytes with contrasting morphological structures. Freshwater Biology, 2017, 62(10), 1783-1793. http://dx.doi.org/10.1111/ fwb.12991.

HILL, W.R. Effects of light. In: R.J. STEVENSON, M.L. BOTHWELL and R.L. LOWE, eds. Algal Ecology. New York: Academic Press, 1996, 753 p. http://dx.doi.org/10.1016/B978-0126684506/50034-5.

HOLDING, K.L., GILL, R.A. and CARTER, J. The relationship between epilithic periphyton (biofilm) bound metals and metals bound to sediments in freshwater systems. Environmental Geochemistry and Health, 2003, 25(1), 87-93. http://dx.doi. org/10.1023/A:1021205101133. PMid:12901083.

JEPPESEN, E., SØNDERGAARD, M. and LIU, Z. Lake restoration and management in a climate change perspective: an introduction. Water (Basel), 2017, 9(2), 122. http://dx.doi.org/10.3390/w9020122.

JÖBGEN, A., PALM, A. and MELKONIAN, M. Phosphorus removal from eutrophic lakes using periphyton on submerged artificial substrata. Hydrobiologia, 2004, 528(1-3), 123-142. http:// dx.doi.org/10.1007/s10750-004-2337-5.

JONES, R.I. Mixotrophy in planktonic protists: an overview. Freshwater Biology, 2000, 45(2), 
219-226. http://dx.doi.org/10.1046/j.13652427.2000.00672.x.

KLIGERMAN, D.C. and BOUWER, E.J. Prospects for biodiesel production from algae-based wastewater treatment in Brazil: A review. Renewable \& Sustainable Energy Reviews, 2015, 52(C), 1834-1846. http:// dx.doi.org/10.1016/j.rser.2015.08.030.

LAMBERT, A. S., DABRIN, A., MORIN, S., GAHOU, J., FOULQUIER, A., COQUERY, M. and PESCE, $S$. Temperature modulates phototrophic periphyton response to chronic copper exposure. Environmental Pollution, 2016, 208, 821-829.

LIN, Z., LI, J., LUAN, Y. and DAI, W. Application of algae for heavy metal adsorption: A 20-year metaanalysis. Ecotoxicology and Environmental Safety, 2020, 190, 110089. http://dx.doi.org/10.1016/j. ecoenv.2019.110089. PMid:31896472.

LIU, Z., HU, J., ZHONG, P., ZHANG, X., NING, J., LARSEN, S.E., CHEN, D., GAO, Y., HE, H. and JEPPESEN, E. Successful restoration of a tropical shallow eutrophic lake: Strong bottom-up but weak top-down effects recorded. Water Research, 2018, 146(1), 88-97. http://dx.doi.org/10.1016/j. watres.2018.09.007. PMid:30236468.

LOCK, M.A., WALLACE, R.R., COSTERTON, J.W., VENTULLO, R.M. and CHARLTON, S.E. River epilithon: toward a structural functional model. Oikos, 1984, 42(1), 10-12. http://dx.doi. org/10.2307/3544604.

LU, H., YANG, L., SHABBIR, S. and WU, Y. The adsorption process during inorganic phosphorus removal by cultured periphyton. Environmental Science and Pollution Research International, 2014, 21(14), 8782-8791. http://dx.doi.org/10.1007/ s11356-014-2813-z. PMid:24728572.

MILSTEIN, A., PERETZ, Y. and HARPAZ, S. Culture of organic tilapia to market size in periphyton based ponds with reduced feed inputs. Aquaculture Research, 2009, 40(1), 55-59. http://dx.doi.org/10.1111/ j.1365-2109.2008.02062.x.

MORASHASHI, A.C., JESUS, T.A., ROSA, D.S., HARADA, J. and BICUDO, D.C. Avaliaçáo e comparação do acúmulo de fósforo por biofilme formado sobre lâminas de vidro e de filme polimérico biodegradável (Ecovio ${ }^{\circledR}$ modificado). Revista Brasileira de Ciência. Tecnologia e Inovação, 2019, 4(2), 131-145. http://dx.doi.org/10.18554/rbcti. v4i2.3696.

OLIVEIRA, D.E., FERRAGUT, C. and BICUDO, D.C. Relationships between environmental factors, periphyton biomass and nutrient content in Garças Reservoir, a hypereutrophic tropical reservoir in southeastern Brazil. Lakes and Reservoirs, 2010, 15(2), 129-137. http://dx.doi.org/10.1111/j.14401770.2010.00428.x.
PAULSSON, M., MÅNSSON, V. and BLANCK, H. Effects of zinc on the phosphorus availability to periphyton communities from the river Göta Älv. Aquatic Toxicology (Amsterdam, Netherlands), 2002, 56(2), 103-113. http://dx.doi.org/10.1016/S0166445X(01)00189-8. PMid:11755699.

PEREIRA, R.C.C., MACHADO, A.H. and SILVA, G.G. (Re) Conhecendo o PET. Química Nova na Escola, 2002, 15, 3-5. [viewed 14 Jan. 2020]. Available from: http://qnesc.sbq.org.br/online/ qnesc15/v15a01.pdf

ROONEY, R.C., DAVY, C., GILBERT, J., PROSSER, R., ROBICHAUD, C. and SHEEDY, C. Periphyton bioconcentrates pesticides downstream of catchment dominated by agricultural land use. The Science of the Total Environment, 2020, 702(1), 131172. http://dx.doi.org/10.1016/j.scitotenv.2019.134472. PMid:31731130.

ROESELERS, G., VAN LOOSDRECHT, M.C.M. and MUYZER, G. Phototrophic biofilms and their potential applications. Journal of Applied Phycology, 2008, 20(3), 227-235. http://dx.doi.org/10.1007/ s10811-007-9223-2. PMid:19396356.

SCHINDLER, D.W., HECKY, R.E., FINDLAY, D.L., STAINTON, M.P., PARKER, B.R., PATERSON, M.J., BEATY, K.G.M., LYNG, M. and KASIAN, S.E.M. Eutrophication of lakes cannot be controlled by reducing nitrogen input: Results of a 37-year whole-ecosystem experiment. Proceedings of the National Academy of Sciences of the United States of America, 2009, 105(32), 11254-11258. http://dx.doi. org/10.1073/pnas.0805108105. PMid:18667696.

SCHINDLER, D.W. The dilemma of controlling cultural eutrophication of lakes. Proceedings. Biological Sciences, 2012, 279(1746), 4322-4333. http://dx.doi. org/10.1098/rspb.2012.1032. PMid:22915669.

SERRA, A., GUASCH, H., ADMIRAAL, W., VAN DER GEEST, H.G. and VAN BEUSEKOM, S.A.M. Influence of phosphorus on copper sensitivity of fluvial periphyton: the role of chemical, physiological and community-related factors. Ecotoxicology (London, England), 2010, 19(4), 770-780. http://dx.doi. org/10.1007/s10646-009-0454-7. PMid:20024616.

SIQUEIRA, N.S. and RODRIGUES, L. Biomassa perifítica em tanques-rede de criação de tilápia do Nilo Oreochromis niloticus (Linneau, 1758). Boletim do Instituto de Pesca, 2009, 35(2), 181-190. [viewed 14 Jan. 2020]. Available from: https://www.pesca. agricultura.sp.gov.br/35_2_181-190.pdf

SØNDERGAARD, M., BJERRING, R. and JEPPESEN, E. Persistent internal phosphorus loading during summer in shallow eutrophic lakes. Hydrobiologia, 2013, 710(1), 95-107. http://dx.doi. org/10.1007/s10750-012-1091-3.

STEVENSON, R.J. and STOERMER, E.F. Luxury consumption of phosphorus by five Cladophora epiphytes in Lake Huron. Transactions of the American 
Microscopical Society, 1982, 101(2), 151-161. http:// dx.doi.org/10.2307/3225768. PMid:7135703.

TRBOJEVIĆ, I., JOVANOVIĆ, J., KOSTIĆ, D., POPOVIĆ, S., KRIZMANIĆ, J., KARADŽIĆ, V. and SIMIĆ, G.S. Structure and succession of periphyton in an urban reservoir: artificial substrate specificity. Oceanological and Hydrobiological Studies, 2017, 46(4), 379-392. http://dx.doi.org/10.1515/ ohs-2017-0038.

TRBOJEVIĆ, I., JOVANOVIĆ, J., KOSTIĆ, D., POPOVIĆ, S., PREDOJEVIĆ, D., KARADŽIĆ, V. and SIMIĆ, G.S. Periphyton Developed on Artificial Substrates: Effect of Substrate Type and Incubation Depth. Russian Journal of Ecology, 2018, 49(2), 135-142. http://dx.doi.org/10.1134/ S1067413618020145.

TU, L., JAROSCH, K.A., SCHNEIDER, T. and GROSJEAN, M. Phosphorus fractions in sediments and their relevance for historical lake eutrophication in the Ponte Tresa basin (Lake Lugano, Switzerland) since 1959. The Science of the Total Environment, 2019, 685, 806-817. http://dx.doi.org/10.1016/j. scitotenv.2019.06.243. PMid:31238284.

VADEB O N COEUR, Y., KALF F, J., CHRISTOFFERSEN, K. and JEPPESEN, E. Substratum as a driver of variation in periphyton chlorophyll and productivity in lakes. Journal of the North American Benthological Society, 2006, 25(2), 379-392. http://dx.doi.org/10.1899/08873593(2006)25[379:SAADOV]2.0.CO;2.

VALDERRAMA, G.C. The simultaneous analysis of total nitrogen and total phosphorus in natural waters. Marine Chemistry, 1981, 10(2), 109-112. http:// dx.doi.org/10.1016/0304-4203(81)90027-X.

VAN OOSTERHOUT, F., WAAJEN, G., YASSERI, S., MARINHO, M.M., NOYMA, N.P., MUCCI, M., DOUGLAS, G. and LURLING, M. Lanthanum in water, sediment, macrophytes and chironomid larvae following application of Lanthanum modified bentonite to lake Rauwbraken (The Netherlands). The Science of the Total Environment, 2020, 706, 135188. http://dx.doi.org/10.1016/j.scitotenv.2019.135188. PMid:31855642.

VYMAZAL, J. Short-term uptake of heavy metals by periphyton algae. Hydrobiologia, 1984, 119(3), 171179. http://dx.doi.org/10.1007/BF00015208.

WAGNER, M., SCHERER, C., ALVAREZ-MUÑOZ, D., BRENNHOLT, N., BOURRAIN, X., BUCHINGER, S. and RODRIGUEZ-MOZAZ, S. Microplastics in freshwater ecosystems: what we know and what we need to know. Environmental Sciences Europe, 2014, 26(1), 12. http://dx.doi. org/10.1186/s12302-014-0012-7. PMid:28936382.

WANG, S., LI, J., ZHANG, B., SPYRAKOS, E., TYLER, A.N., SHEN, Q., ZHANG, F., KUSTER,
T., LEHMANN, M.K., WU, Y. and PENG, D. Trophic state assessment of global inland waters using a MODIS-derived Forel-Ule index. Remote Sensing of Environment, 2018, 217, 444-460. http://dx.doi. org/10.1016/j.rse.2018.08.026.

WU, N., DONG, X., LIU, Y., WANG, C. and PEDESERN, A.B. Using river microalgae as indicators for freshwater biomonitoring: Review of published research and future directions. Ecological Indicators, 2017, 81, 124-131. http://dx.doi. org/10.1016/j.ecolind.2017.05.066.

WU, Y., ZHANG, S., ZHAO, H. and YANG, L. Environmentally benign periphyton bioreactors for controlling cyanobacterial growth. Bioresource Technology, 2010, 101(24), 9681-9687. http:// dx.doi.org/10.1016/j.biortech.2010.07.063. PMid:20702088.

YAMADA-FERRAZ, T.M., SUEITT, A.P.E., OLIVEIRA, A.F., BOTTA, C.M.R., FADINI, P.S., NASCIMENTO, M.R.L., FARIA, B.M. and MOZETO, A.A. Assessment of Phoslock ${ }^{\circledR}$ application in a tropical eutrophic reservoir: An integrated evaluation from laboratory to field experiments. Environmental Technology \& Inovation, 2015, 4, 194-205. http://dx.doi.org/10.1016/j. eti.2015.07.002.

ZENG, J. and WANG, W.X. Temperature and irradiance influences on cadmium and zinc uptake and toxicity in a freshwater cyanobacterium, Microcystis aeruginosa. Journal of Hazardous Materials, 2011, 190(1-3), 922-929. http://dx.doi.org/10.1016/j. jhazmat.2011.04.009. PMid:21536379.

ZHANG, N., LI, H., JEPPESEN, E. and LI, W. Influence of substrate type on periphyton biomass and nutrient state at contrasting high nutrient levels in a subtropical shallow lake. Hydrobiologia, 2013, 710(1), 129-141. http://dx.doi.org/10.1007/s10750012-1287-6.

ZHAO, Y., YANG, Z., XIA, X. and WANG, F. A shallow lake remediation regime with Phragmites australis: Incorporating nutrient removal and water evapotranspiration. Water Research, 2012, 46(17), 5635-5644. http://dx.doi.org/10.1016/j. watres.2012.07.053. PMid:22921585.

ZHOU, A., TANG, H. and WANG, D. Phosphorus adsorption on natural sediments: modeling and effects of $\mathrm{pH}$ and sediment composition. Water Research, 2005, 39(7), 1245-1254. http://dx.doi. org/10.1016/j.watres.2005.01.026. PMid:15862324.

Received: 14 January 2020 Accepted: 04 May 2021

Associate Editors: Irineu Bianchini Junior, Antonio Fernando Monteiro Camargo. 